Estuarine, Coastal and Shelf Science

November 2018, Volume 212, Pages 210-218

http://dx.doi.org/10.1016/i.ecss.2018.07.008

http://archimer.ifremer.fr/doc/00449/56051/

(c) 2018 Elsevier Ltd. All rights reserved.

\title{
Otolith fingerprints as natural tags to identify juvenile fish life in ports
}

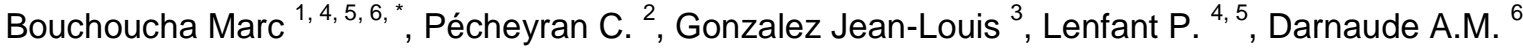

${ }^{1}$ Lab Environnement Ressources Provence Azur Corse, Centre Ifremer de Méditerranée ZP de

Brégaillon, CS 20330, 83507, La Seyne-sur-Mer, France

${ }^{2}$ Univ. Pau et des Pays de l'Adour, CNRS, LCABIE-IPREM UMR 5254, 64053, Pau, France

${ }^{3}$ Lab. Biogéochimie des Contaminants Métalliques, Centre Ifremer de Méditerranée ZP de Brégaillon, CS 20330, 83507, La Seyne-sur-Mer, France

${ }^{4}$ Univ. Perpignan Via Domitia, CEntre de Formation et de Recherche sur les Environnements

Méditerranéens, UMR 5110, 58 Avenue Paul Alduy, F-66860, Perpignan, France

${ }^{5}$ CNRS, CEntre de Formation et de Recherche sur les Environnements Méditerranéens, UMR 5110, 58

Avenue Paul Alduy, F-66860, Perpignan, France

${ }^{6}$ CNRS, UMR MARBEC 9190. CC093, Université de Montpellier, Place Eugène Bataillon, 34095,

Montpellier, France

* Corresponding author : Marc Bouchoucha, email address : marc.bouchoucha@ifremer.fr

\begin{abstract}
:
The construction of ports has caused substantial habitat destruction in coastal areas previously used as nursery grounds by many fish species, with consequences to fish stocks. These artificial coastal areas might provide alternative nursery habitats for several species for juvenile fish abundances and growth in ports, although their contribution to adult stocks had never been estimated. The variability of otolith composition in the juveniles of two Diplodus species was investigated in three contrasting port areas and two adjacent coastal juvenile habitats of the Bay of Toulon (northwestern Mediterranean) in order to determine the possible use of otolith fingerprints as natural tags for the identification of juvenile fishes in ports. The global accuracy of discrimination between ports and coastal areas was very high (94\%) irrespective of species, suggesting that otolith fingerprints can be used with confidence to retrospectively identify past residency in the ports of this bay. However, Ba was systematically the most discriminating element, since its concentrations in otoliths were generally higher outside ports than in inside them, probably due to river runoff. Moreover, otolith signatures varied greatly by species and between sampling sites. Furthermore, although $\mathrm{Cu}$ and $\mathrm{Pb}$ concentrations in water were at least 2.3-34-fold higher inside ports than outside, this was not consistently reflected in fish otoliths, confirming that spatial differences in otolith concentrations depend on the species and do not directly reflect differences in environmental contamination levels. Therefore, it seems unlikely that otolith microchemistry could provide a universal fingerprint capable of discriminating ports from other coastal areas. Nevertheless, the contribution of ports to adult fish populations can be determined well by establishing a library of otolith fingerprints for all juvenile habitats.
\end{abstract}

Keywords : Coastal areas, Nursery habitats, Fish, LA-ICPMS, Contamination 
2 Shallow coastal areas are used as nursery habitats by many fish species as they are highly productive environments (Harmelin-Vivien et al., 1995; Macpherson et al., 1997; Beck et al., 2001). However,

4 they are increasingly threatened by urbanization (Lotze et al., 2006; Airoldi and Beck, 2007; Halpern et al., 2008), in particular by port constructions (Rodríguez-Rodríguez et al., 2015). Several recent studies have suggested that coastal man-made infrastructures, particularly those found inside ports, might provide suitable alternative nursery habitats for certain fish species (e.g. Pizzolon et al., 2008; Bouchoucha et al., 2016; Mercader et al., 2017). However, these conclusions were solely based on fish abundance (Bouchoucha et al., 2016; Mercader et al., 2017) or post-settlement growth and condition (Bouchoucha et al., 2018) in ports when, in theory, fish nursery grounds are defined according to three conditions: they support high abundances of juveniles, they sustain faster somatic growth rates and they also enhance fish survival so their populations contribute more to the final adult stock (Beck et al., 2001). Therefore, the correct estimation of the nursery role played by ports implies estimating the relative contribution of port juvenile habitats to adult stocks.

Among the tools available for this purpose, otolith microchemistry is increasingly used (Campana et al., 2000; Elsdon et al., 2008; Dierking et al., 2012; Fortunato et al., 2017). Otoliths are paired calcified structures located in the inner ear of teleost fishes. They have been widely used in marine ecology and fishery research to describe population age structure, assess connectivity between fish stocks and study individual migration patterns (Campana, 1999; Dierking et al., 2012). Otoliths are particularly well suited for these applications because of three key properties. Firstly, they grow continuously throughout daily centrifugal accretions of calcium carbonate $(\mathrm{CaCO} 3)$ aragonitic crystals on protein layers (Campana and Neilson, 1985). Secondly, as otoliths are acellular and metabolically inert, they are neither reworked nor resorbed, even during times of starvation (Campana and Neilson, 1985). Chemical fingerprints are thus retained permanently within the microstructure (Panfili, 2002). Thirdly, the incorporation of some chemical elements in the otolith is somehow influenced by the ambient water (Elsdon and Gillanders, 2003; Sturrock et al., 2012). The chemical composition of the inner region within adult fish otoliths can thus be used as a natural tag to retrospectively assign their juvenile origin (e.g. Gillanders and Kingsford, 2000; Vasconcelos et al., 2008; Tournois et al., 2017).

To achieve this, the habitats must differ sufficiently in their environmental conditions, whether because of varied anthropogenic influences or due to natural variations (Barnes and Gillanders, 2013;

31 Sturrock et al., 2015). As the recipients of industrial and domestic wastes, ports are generally subject to high chemical contaminations (Darbra et al., 2004) and seem particularly suited for studies using 
elemental fingerprints in otoliths as natural tags. However, the incorporation of elements in otoliths is more complex than their mere concentration in the ambient water as it is affected by their bioavailability, the physiological state of individual fish (Sturrock et al., 2015) and the synergetic/concomitant effects of temperature, salinity and water chemistry (Elsdon and Gillanders, 2004). While some elements (e.g., Sr, Ba) appear to directly reflect ambient water concentrations, others (e.g. $\mathrm{Cu}, \mathrm{Zn}$ ) are physiologically regulated and less likely to reflect surrounding environmental conditions (Campana, 1999; Sturrock et al., 2012; Izzo et al., 2018). Moreover, some elements (e.g. $\mathrm{Cu}, \mathrm{Pb}$ ) can affect fish condition and metabolic rates leading to variations in their incorporation in otoliths (Geffen et al., 1998; Hamer and Jenkins, 2007).

In this context, the specific aim of this study was to investigate differences in otolith composition among fish juveniles captured after several months of residency in varied habitats located inside and outside ports. Using two Diplodus species with different recruitment periods and five contrasting sites (three inside ports and two outside them, in adjacent juvenile habitats) located in the Bay of Toulon (Northwestern Mediterranean), we tested whether otolith elemental fingerprints could be used with confidence to retrospectively identify previous fish residency in ports. This would allow the reliable assessment of the contribution of ports to adult fish populations and thus better evaluation of the potential consequences of port infrastructures for fish stock dynamics. The hypothesis tested here was that the otoliths of fish captured inside ports would contain consistently higher concentrations of port related trace elements (such as $\mathrm{Pb}, \mathrm{Cu}, \mathrm{Zn}$, etc.) than those of fish from the other coastal areas.

Materials and Methods

Model species

Two Diplodus species, D. sargus sargus (Linnaeus, 1758), hereafter D. sargus, and D. vulgaris (Geoffroy Saint-Hilaire, 1817) were chosen for this study. Both are very common in the Mediterranean (Coll et al., 2004; Morales-Nin et al., 2005; Lloret et al., 2008) and their juveniles are found in high abundances inside ports (Clynick, 2006; Bouchoucha et al., 2016). However there is temporal segregation between settlement periods of the two species (García-Rubies and Macpherson, 1995; Harmelin-Vivien et al., 1995; Vigliola et al., 1998; Cheminee et al., 2011; Ventura et al., 2014; Bouchoucha et al., 2016): D. sargus generally settles in one pulse, in May-June, and usually leaves its nursery grounds in September while D. vulgaris generally settles in two pulses, in NovemberDecember and in January-February, the first pulse being predominant, and leaves its nursery grounds in June-July. However, in the both species, spatial variability in settlement period may occur (Vigliola et al., 1998). Moreover, migrations between nursery areas is very limited for both species (Macpherson et al., 1997). Therefore, investigating variations in otolith chemical composition in these two species should allow reaching conclusions regarding the temporal stability of the otolith elemental fingerprints if any. 
Study area, fish sampling and environmental data

This study was carried out in the Bay of Toulon (Northwestern Mediterranean, Fig. 1) which is divided into the Large Bay $\left(42.2 \mathrm{~km}^{2}\right)$ and the Small Bay $\left(9.8 \mathrm{~km}^{2}\right)$, separated by a breakwater $(1,200$ $\mathrm{m})$ built in the nineteenth century (Fig.1). The Small Bay harbors one of France's largest industrial ports, the biggest naval port of the Mediterranean, and several marinas. Both the historic and present activities pursued in this part of the bay result in the heavy multi-contamination of its sedimentary compartment (Tessier et al., 2011; Pougnet et al., 2014; Dang et al., 2015) and water column (Jean et al., 2012; Dang et al., 2015). For example, sediment concentrations of $\mathrm{Pb}$ and $\mathrm{Cu}$ within the naval port of Toulon are among the highest ever measured in a marine area (Tessier et al., 2011). Conversely, the Large Bay is only slightly impacted by human activities and offers shallow rocky areas whose characteristics correspond to suitable nursery areas for many juvenile fishes (Harmelin-Vivien et al., 1995; Cheminee et al., 2011). Contamination levels in this part of the bay are low (Tessier et al., 2011). Therefore, the Bay of Toulon is particularly suited for investigating differences in fish otolith composition between juvenile habitats located within and outside ports.

In this work, five contrasting sampling sites were selected in the Bay of Toulon: three representative of the different types of port present in the Bay of Toulon and two representative of the other types of coastal habitats available for the juveniles of local rocky fishes. The first sampling site (STM) was located in the Saint-Mandrier marina. This marina, representative of the marinas found in the Small Bay of Toulon, harbors 800 boats and pleasure craft and its average depth varies between 2.5 and $4 \mathrm{~m}$. The second site (TLN) was located about $500 \mathrm{~m}$ from the port of Toulon, which is the biggest naval port in the Mediterranean (30 warships and nuclear attack submarines) and a major ferry terminal (around 1,000 rotations and 1.2 million passengers a year). The area around the TLN sampling site is one of the most contaminated of the Bay of Toulon (Tessier et al., 2011; Wafo et al., 2016). The third site (IFR) was positioned further in the Small Bay (fig. 1), within a port harboring a part of the French oceanographic fleet. The fourth sampling site (DLE) was located on the seaward side of the breakwater that separates the Small from the Large Bay (Fig. 1), in an area considered as slightly impacted by port pollution (Tessier et al., 2011; Wafo et al., 2016). As the seaward sides of peripheral breakwaters are generally considered favorable juvenile fish habitats (Ruitton et al., 2000; Guidetti, 2004; Clynick, 2006; Pizzolon et al., 2008; Dufour et al., 2009; Pastor et al., 2013), the DLE site was considered in this study as representative of the non-polluted artificial juvenile habitats available for rocky fishes within the Bay of Toulon. Physical habitat characteristics (substrate, depth, etc.) are equivalent in the STM, TLN, IFR and DLE sampling sites. The last sampling site (MAG) was located in a natural cove (Anse Magaud) whose characteristics match those of the successful benthic settlement of Diplodus species, i.e. shallow water habitats (between 0 and $2 \mathrm{~m}$ ) protected from prevailing winds and characterized by gentle slopes covered with sand, pebbles and boulders 
(Harmelin-Vivien et al., 1995; Cheminee et al., 2011). Therefore, this site is considered as representative of the natural rocky fish nursery habitats available in the Bay of Toulon.

Sampling took place in September 2014 for D. sargus and late June / early July 2015 for D. vulgaris, i.e. during the month preceding the departure of the juveniles of each species from nursery their areas to join adult populations. Between 9 and 14 juveniles per species were sampled from each site using hand-nets. Juveniles were discriminated following the size and morphometric criteria given by Vigliola and Harmelin-Vivien (2001).

Trace element concentrations in the water column were assessed at each sampling site using the diffusive gradient in thin film (DGT) device which allows gathering integrative values of the most labile dissolved concentrations of metal species in water (Davison and Zhang, 1994). By accumulating ionic forms and weakly dissociable complexes (hereafter named the DGT-labile fraction) on a Chelex 100 resin, proportionally to their water concentration and exposure time, "Standard" DGTs "concentrate" the most highly "labile" dissolved cations, as defined operationally (hydrated ions, mineral complexes, and "weak" or "rapidly dissociable" organic complexes). This DGT- labile fraction is generally considered more representative of potentially bioavailable fraction than the total metal concentration (Zhang and Davison, 2001; Odzak et al., 2002; Twiss and Moffett, 2002). In our study, three DGTs were immersed at $1.5 \mathrm{~m}$ depth for 15 days each month, from January to July 2015, at each of the five sampling sites. Three DGTs were selected as controls and not immersed in the seawater. During this period, temperature and salinity data were also recorded monthly at each site using a CTD probe (YSI Pro30).

Otolith analyses

Fish juveniles were transported on ice to the laboratory, measured (Total length TL, in mm), weighed (total mass, in $\mathrm{mg}$ ) and stored at $-20^{\circ} \mathrm{C}$ until otolith extraction. In accordance with Campana et al. (2000), all the materials used for otolith extraction and handling were decontaminated in $4 \%$ ultrapure nitric acid baths, triple rinsed with ultrapure water $(18.2 \mathrm{M} \Omega)$ and dried on a Class 100 clean bench. Diplodus sagital otoliths were extracted using plastic forceps under binocular lens, rinsed with ultrapure water and cleaned of adhering tissues. They were then sonicated for $5 \mathrm{~min}$ in ultrapure water, triple rinsed again and dried on the same laminar clean bench.

Right otoliths from all fish were embedded separately in epoxy resin (Araldite 2020, Escil) and cut in the transverse plane using a saw with a diamond coated blade (Buehler IsoMet 1000 precision saw). Individual otolith sections were then polished using 1200, 2400 and 4000 silicate papers to expose the core (average thickness $\approx 300 \mu \mathrm{m}$ ). A final sonication was carried out for surface decontamination before storage in dust-free conditions until analysis.

In addition to ${ }^{43} \mathrm{Ca}$, otolith elemental compositions of nine elements $\left({ }^{24} \mathrm{Mg},{ }^{51} \mathrm{~V},{ }^{55} \mathrm{Mn},{ }^{63} \mathrm{Cu},{ }^{66} \mathrm{Zn},{ }^{88} \mathrm{Sr}\right.$, ${ }^{118} \mathrm{Sn},{ }^{138} \mathrm{Ba}$ and ${ }^{208} \mathrm{~Pb}$ ) were assessed using a $257 \mathrm{~nm}$ high repetition rate femtosecond (fs) Laser 
Ablation system (Lambda 3, Nexeya, France) coupled with a High Resolution Inductively Coupled Plasma Mass Spectrometer (HR-ICPMS) fitted with a jet interface (Element XR, Thermo Bremen) (fsLA-HRICPMS). The laser in this system delivers $360 \mathrm{fs}$ pulses at a wave-length s of $257 \mathrm{~nm}$ and can be operated at high repetition rates (up to $100 \mathrm{kHz}$ ). By combining the high repetition rate (500 $\mathrm{Hz}$ ) of the laser with a fast back and forth movement $\left(1 \mathrm{~mm} \cdot \mathrm{s}^{-1}\right)$ of its beam (diameter $20 \mu \mathrm{m}$, energy $45 \mu \mathrm{J}$.pulse ${ }^{-1}$ ), an elongated virtual beam shape (width $150 \mu \mathrm{m}$ ) was simulated at a speed of $5 \mu \mathrm{m} . \mathrm{s}^{-1}$. For each otolith analyzed, a linear raster of $150 \mu \mathrm{m}$ length consisting of approx. 30 sequential measures, was taken along the longest radius, starting at $200 \mu \mathrm{m}$ after the settlement mark (Fig. 2). This portion of the otolith corresponds approximately to the third month of fish juvenile life. This was estimated through a microstrucural analysis and a daily increment counts performed on the left otolith of each fish (Vigliola, 1997). For each otolith, the laser was used to preclean the otolith surface of interest prior to ablation. To do this, the laser was operated at a lower repetition rate $(100 \mathrm{~Hz})$ and a faster stage movement $\left(400 \mu \mathrm{m} . \mathrm{s}^{-1}\right.$ instead of $\left.5 \mu \mathrm{m} . \mathrm{s}^{-1}\right)$ in order to prevent excessive in-depth removal (resulting ablation depth $=2-5 \mu \mathrm{m}$ ).

The ablation cell was flushed with Helium $\left(700 \mathrm{ml}^{\mathrm{min}}{ }^{-1}\right)$ to carry the particles to the ICPMS, and argon (300 ml. $\mathrm{min}^{-1}$ ) was mixed with the helium stream using a Y-piece to adjust the optimal particle atomization conditions in the plasma. The plasma was also fed with nitrogen $\left(10 \mathrm{ml} . \mathrm{min}^{-1}\right)$ to enhance signal sensitivity.

As light elements are prone to interference from polyatomic and double charged isotopes, the mass spectrometer was used in medium resolution mode $(\mathrm{R}=4000)$ to optimize interference removal during analysis. Calcium was used as an internal standard for each ablation to correct for instrumental error (in terms of ablation yield and detection). The quantification of elements in the otoliths was achieved by external calibration using three NIST glass standards (610, 612 and 614). Two otolith Certified Reference Materials (NIES22 and FEBS 1 were also pelletized and used to control the quality of the analysis of selected elements in the fish otoliths. The average limits of detection (LOD) over a three month-session based on the threefold standard deviation of blank gas were 2.0, 0.8, 0.8, 4.2, 13.2, 1.6, 8.1, 0.3 and $0.6 \mu \mathrm{g} . \mathrm{g}^{-1}$ in the otoliths for ${ }^{24} \mathrm{Mg},{ }^{51} \mathrm{~V},{ }^{55} \mathrm{Mn},{ }^{63} \mathrm{Cu},{ }^{66} \mathrm{Zn},{ }^{88} \mathrm{Sr},{ }^{118} \mathrm{Sn},{ }^{138} \mathrm{Ba}$ and ${ }^{208} \mathrm{~Pb}$, respectively.

Water analyses

Following the deployment of the DGTs, the Chelex resin of the probes was peeled off in the laboratory and trace elements were extracted in $1.8 \mathrm{ml}$ of $1 \mathrm{M}$ ultrapure nitric acid $(24-48 \mathrm{~h})$. Concentrations in the acid extracts were analyzed for four trace elements $(\mathrm{Pb}, \mathrm{Mn}, \mathrm{Zn}$ and $\mathrm{Cu})$ using ICP-MS to determine the mass of metal (M) accumulated in the Chelex 100 resin. These elements were chosen because they can be measured using DGT and are representative of port and human activities in the Bay of Toulon (Tessier et al., 2011). 
173 For each trace element, the average labile concentrations in water (CDGT) were calculated using the

174 following equation (Zhang et al., 1995):

$\mathrm{CDGT}=(\mathrm{M} . \Delta \mathrm{g}) /($ Dm.t.A $)$

176

177

178

179

180

181

182

183

184

185

186

187

where $\mathrm{M}$ is the mass of the trace element accumulated in the resin, $\Delta \mathrm{g}$ is the diffusive layer thickness, Dm is the diffusion coefficient of the trace element provided by DGT Research (www.dgtresearch.com), $\mathrm{t}$ is the immersion of the DGT probe, and A is the exposure area.

Statistical analyses

Otolith concentrations for all elements were transformed to their ratio to Calcium (element:Ca ratio) and checked for normality and homoscedasticity prior to statistical analyses. Since none of the assumptions were satisfied, even after transformation, Mann-Whitney tests and Kruskall-Wallis tests followed by Steel-Dwass-Chritchlow-Fligner post-hoc tests were used. For each species spatial variation in elemental ratios were analyzed according to habitat type (inside or outside a port) and the sampling site, respectively. Spatial variation in the elemental composition of water was also tested using Kruskall-Wallis tests followed by Steel-Dwass-Chritchlow-Fligner post-hoc tests.

In accordance with Mercier et al. (2011), accuracy in habitat type and sampling site identification using otolith elemental fingerprints were investigated for each species using the Random Forest (RF) algorithm (Breiman, 2001). RF is a machine-learning classification method which requires no a priori assumptions regarding data distribution and can extract signals from complex datasets. Therefore it is very effective for discriminating local coastal habitats based on otolith elemental fingerprints (e.g. Mercier et al., 2012; Regnier et al., 2017; Tournois et al., 2017) even in the presence of skewness (Mercier et al., 2011; Jones et al., 2017). Details of the method are provided in Mercier et al. (2011) and Tournois et al. (2013). For each of the individual measures performed on the otoliths, the RF predicts habitat origin by running it through 5000 trees of a classifier (built from known signatures from all habitats) and then using "majority rules" to reach a consensus between all the trees (Tournois et al., 2017). In our case, to identify the list of elements needed to reach maximum accuracy in habitat discrimination, a portion of the dataset (75\%) was randomly selected to build the RF classifier and the remaining portion (25\%) was used to calculate the global classification accuracy and the percentage of correct re-assignments for each location (cross validation procedure). This cross-validation procedure was applied to all the possible combinations of two to nine of the nine elements measured in the otoliths (Ca was used as an internal standard).

Once the optimal RF classifier had been identified, values for True Skill Statistics per habitat (TSS, Allouche et al., 2006) were calculated to evaluate the successful discrimination for each location. Contrary to habitat accuracy, TSS accounts for true negative prediction, namely for fish whose absence from a given site was correctly predicted. TSS ranges from -1 to 1 , where 1 indicates $100 \%$ correct prediction of presence or absence in a given habitat (Tournois et al., 2017). Finally, the 
contribution of each element to the global success of discrimination was evaluated using the mean decrease in the Gini index (Archer and Kimes, 2008): the higher it is, the more discriminative the element (Tournois et al., 2013). All data processing and statistical analyses were performed using the R software (R Core Team, 2014) and PRIMER 6 software with the PERMANOVA add-on (Clarke and Warwick, 2001).

Results

Water concentrations in $\mathrm{Cu}$ and $\mathrm{Pb}$ differed significantly $(\mathrm{p}<0.0001)$ according to the sampling sites (Table 1), with consistently lower values at MAG and higher ones in ports. However, water concentrations in $\mathrm{Cu}$ were maximal at STM (2 $971 \pm 997$ ng. $\mathrm{l}^{-1}$ ), while for $\mathrm{Pb}$, the highest values were recorded at TLN $\left(328 \pm 107\right.$ ng. $\left.1^{-1}\right)$. No significant differences $(\mathrm{p} \geq 0.06)$ in $\mathrm{Mn}$ and $\mathrm{Zn}$ concentrations in water were observed among the sites (Table 1).

Spatial differences in otolith elemental concentrations were not consistent for all elements and between species (Fig.3). Ba, Mn and Sr values were always significantly higher $(\mathrm{p}<0.001)$ outside ports while for $\mathrm{Mg}$ and $\mathrm{Sn}$ otolith concentrations were consistently higher inside them ( $\mathrm{p}$ 0.018). For $\mathrm{Cu}$, the values in ports were significantly higher for D. sargus $(\mathrm{p}<0.001)$ but lower for $D$. vulgaris $(\mathrm{p}$ $<0.0001)$. For $\mathrm{Pb}$, no significant variation ( $\mathrm{p}>0.063$ ) was observed between the two habitat types (inside or outside ports), irrespective of species. Finally, for Zn, variations were not significant between habitat types for $D$. sargus $(\mathrm{p}=1)$ whereas, for $D$. vulgaris the values were higher outside ports $(\mathrm{p}<0.001)$. This pattern was inversed for $\mathrm{V}$.

For both species, discrimination accuracy using RF was always maximal when including eight elements out of nine, $\mathrm{V}$ and $\mathrm{Sr}$ apparently contributing more noise than signal to the discrimination for D. sargus and D. vulgaris, respectively (Fig. 4).

The global discrimination accuracy between ports and adjacent juvenile habitats reached $94 \%$ with TSS $>0.87$ irrespective of species (Fig. 4, Table 2). However, the list of elements included in the RF classifier differed between the two species, the three most useful elements being Ba, Mn and Sn for $D$. sargus and $\mathrm{Ba}, \mathrm{Zn}$ and $\mathrm{Mn}$ for D. vulgaris (Fig. 4).

When considering the five sampling sites separately, using the optimal RF classifier for each species allowed reaching high overall accuracy for both D. sargus (90\%) and D. vulgaris (89\%). Yet again, the most useful elements differed between species, the three most discriminating elements being $\mathrm{Ba}$, $\mathrm{Sn}$ and $\mathrm{Mn}$ for D. sargus and $\mathrm{Ba}, \mathrm{Sn}$ and $\mathrm{Cu}$ for D. vulgaris (Fig. 4). For both species, misclassification errors mostly concerned the STM sampling site (TSS < 0.84) which was to some extent confused with the MAG, DLE and IFR sites due to similar values for $\mathrm{Mn}, \mathrm{Sr}, \mathrm{Cu}, \mathrm{Mg}, \mathrm{Sn}$ and Zn (Table 2, Fig. 3).

Discussion 
As expected from similar studies on other coastal habitats in the Mediterranean (e.g. Di Franco et al., 2011; Fortunato et al., 2017) and elsewhere (e.g. Hamer et al., 2005; Correia et al., 2011), our study showed differences in otolith elemental composition between the five sites sampled. This is not particularly surprising as the sampling sites in this work are highly contrasted in terms of contaminant concentrations (Fig. 3), which are known to influence fish otolith composition (Campana, 1999; Sturrock et al., 2012).

In our study area, otolith signatures inside ports differed markedly from those outside them (especially for $\mathrm{Ba}$ and $\mathrm{Mn}$ ), which should allow accurate the identification of port origin in local adult D. sargus and $D$. vulgaris. For both species, the global classification accuracy obtained between habitat types (inside ports vs. outside) was even higher (94\%) than those found in other coastal systems (Gillanders, 2005; Vasconcelos et al., 2008; Tanner et al., 2011; Tournois et al., 2013). However, considering all five sampling sites separately also led to very high global classification accuracies $(\geq 89 \%)$ and correct re-assignment rates for all of them $(\geq 76 \%)$. Therefore, although port habitats could be confidently identified here for both species, the variability of elemental fingerprints was high among port sites and among adjacent juvenile habitats. This variability has already been pointed out in natural coastal areas and is largely exploited in studies of the dispersal/connectivity of fully marine fishes (Di Franco et al., 2011).

However, this work also showed that otolith elemental concentrations in ports do not consistently reflect their high concentrations in the environment. The relationship between environmental exposure and otolith final concentrations was even inversed for some trace elements. For example, in D. sargus, otoliths from MAG were 1.4-fold more contaminated in $\mathrm{Cu}$ than those from STM (Fig. 4) whereas $\mathrm{Cu}$ concentration was found to be 34-fold higher in the water of MAG (Fig. 3). Similarly, in D. vulgaris, otolith concentrations in Pb were significantly higher in DLE than in TLN (1.3-fold, $p=0.017$ ) whereas this element was 2.6-fold more concentrated in the water at TLN than at DLE (Fig. 3, Fig. 4). Therefore, although the three ports studied were more contaminated than adjacent juvenile habitats, in particular for $\mathrm{Pb}$ and $\mathrm{Cu}$ (Fig. 3), we failed to find at least one trace element for which otolith concentrations would be consistently higher in ports. Up to now few studies have focused on the link between the accumulation of elements in fish otoliths and their bioavailable concentrations in the aquatic environment (e.g. Geffen et al., 1998; Ranaldi and Gagnon, 2009; Daverat et al., 2012), yet those that have done so generally suggested that for many trace elements stored in fish otoliths, in particular $\mathrm{Cu}$ and $\mathrm{Pb}$ (Friedrich and Halden, 2010, 2011; Søndergaard et al., 2015), otolith concentrations largely reflect concentrations in water. This led some authors to conclude that trace element analyses in otoliths could be considered a valuable method for assessing time-resolved trace element exposure due to anthropogenic pollution (Søndergaard et al., 2015; Selleslagh et al., 2016). Several hypotheses can be proposed to explain the inconsistency between our results and these conclusions. Firstly, due to differences in metabolism and otolith formation, trace element 
accumulation in otoliths differs among species (Geffen et al., 1998; Hamer and Jenkins, 2007; Vasconcelos et al., 2007). Therefore, it is possible that otolith trace element incorporation is lower in D. sargus and D. vulgaris juveniles than in the sand goby Pomatoschistus minutus (Geffen et al., 1998), black bream Acanthopagrus butcheri (Ranaldi and Gagnon, 2008), flounder Platichthus flesus (Selleslagh et al., 2016) and common sculpin Myoxocephalus scorpius (Søndergaard et al., 2015), which were all suggested to be adequate for monitoring pollution from point sources. This hypothesis is supported by the fact that lower otolith accumulation rates have already been pointed out for certain trace elements in Diplodus vulgaris, when compared to other species like sole and flounder (Vasconcelos et al., 2007). Secondly, the accumulation of trace elements in fish otoliths not only depends on several factors, including their concentration in the environment and their bioavailability, but also on the physiological state of the fish (affecting the exchange rate between the external and internal environments), and on the mechanisms they use for detoxifying different metals or controlling their growth rate (affecting the rate of accumulation of otolith material). Although juvenile growth for both species is equivalent inside and outside the ports of this area (Bouchoucha et al., 2018), the consequences of juvenile life in ports on their individual physiological state still remain unclear. The influence of anthropogenic stressors on fish metabolism may explain differences in otolith trace element incorporation between the two types of habitat. However, further research is needed to investigate the respective influences of element concentrations in water and spatial variations in fish metabolism on their accumulation in the otoliths of juvenile Diplodus. Nonetheless, we have to reject our initial hypothesis: the otoliths of the juvenile Diplodus captured inside ports, even at the most polluted sites, did not contain higher concentrations of port-related trace elements (such as $\mathrm{Pb}, \mathrm{Cu}, \mathrm{Zn}$, etc.) than those from the juveniles captured in less polluted coastal areas. Therefore, otolith concentrations in these elements cannot be used to retrospectively identify the past residency of adult fish in ports, at least for the two species studied.

For both species, $\mathrm{Ba}$ was the most discriminating element among our sampling sites and between the two types of habitat, as its concentration in the otoliths, with one exception, was consistently higher outside ports than inside them (Fig. 4). This result is surprising as Ba is routinely used to distinguish residence in brackish habitats (reviewed by Elsdon et al., 2008), as its incorporation in otoliths falls when salinity increases (Bath et al., 2000; Elsdon and Gillanders, 2004). Nonetheless, the three port sites investigated here had lower salinities than the two others (Table 1). However, Ba concentrations in otoliths can be modulated by endogenous factors (e.g. fish condition - Izzo et al., 2015), and generally reflect ambient environmental concentrations (Campana, 1999; Elsdon et al., 2008). The DLE and MAG sites are located in the Large Bay of Toulon, close to the two outlets of the Eygoutier river (Fig. 1). As Ba is closely bound to fluvial sediments (Coffey et al., 1997), ambient Ba concentrations may be higher in DLE and MAG than in the three other sampling sites, explaining differences in juvenile fish otolith compositions. Therefore, it is likely that the pattern observed here 
with regard to otolith Ba concentrations is particular to the Bay of Toulon and cannot be extrapolated to other ports and coastal areas.

Finally, the trace elements responsible for the discrimination among the five sampling sites differed according to species, which might suggest that otolith fingerprints should be determined for each species independently and cannot be extrapolated from one species to another. The differences in otolith environmental records between our two species may be due to endogenous processes like physiological regulation (Sturrock et al., 2015) as well as to exogenous ones. Indeed, in the Northwestern Mediterranean, D. vulgaris generally hatches in two pulses, in October-November and in December-January, whereas D. sargus generally hatches only in May-June (Vigliola et al., 1998). Since we analyzed otolith portions corresponding approximately to the third month of life for both species, the environmental signals recorded by the two species do not overlap: for D. vulgaris, the otolith fingerprints correspond to winter/spring conditions while for D. sargus, they correspond to summer ones. Temporal variability in the elemental fingerprints must therefore be evaluated before concluding on the differences in environmental recording capacities among species.

In conclusion, our results showed that otolith microchemistry cannot provide a unique and reliable fingerprint discriminating all ports from other coastal areas. Nevertheless, we showed that, as with natural habitats, otolith microchemistry can provide an effective natural tag for determining the contribution of each port individually, at least in the two species studied. Therefore, in order to assess the contribution of ports to adult fish populations, a library of otolith fingerprints from all juvenile habitats should be established, by species and probably by cohort, and matched against fingerprints from adult otoliths (Thorrold et al., 2001).

Acknowledgements

This work was conducted within the framework of the RESPONSE Project funded by the 'Agence de l'Eau Rhône Mediterranée et Corse' and the Ifremer. We are grateful to G. Barbotin for her assistance for the otolith analyses. Thanks are also due to F. Chavanon and A. Vion for their help during the laboratory work.

References

Airoldi, L., Beck, M.W., 2007. Loss, status and trends for coastal marine habitats of Europe, in: Gibson, R.N., Atkinson, R.J.A., Gordon, J.D.M. (Eds.), Oceanography and Marine Biology, Vol 45. Crc Press-Taylor \& Francis Group, Boca Raton, pp. 345-405.

Allouche, O., Tsoar, A., Kadmon, R., 2006. Assessing the accuracy of species distribution models: prevalence, kappa and the true skill statistic (TSS). J. Appl. Ecol. 43, 1223-1232.

Archer, K.J., Kimes, R.V., 2008. Empirical characterization of random forest variable importance measures. Computational Statistics \& Data Analysis 52, 2249-2260. 
Barnes, T.C., Gillanders, B.M., 2013. Combined effects of extrinsic and intrinsic factors on otolith chemistry: implications for environmental reconstructions. Canadian Journal of Fisheries and Aquatic Sciences 70, 1159-1166.

Bath, G.E., Thorrold, S.R., Jones, C.M., Campana, S.E., McLaren, J.W., Lam, J.W., 2000. Strontium and barium uptake in aragonitic otoliths of marine fish. Geochimica Et Cosmochimica Acta 64, 17051714.

Beck, M.W., Heck, K.L., Able, K.W., Childers, D.L., Eggleston, D.B., Gillanders, B.M., Halpern, B., Hays, C.G., Hoshino, K., Minello, T.J., Orth, R.J., Sheridan, P.F., Weinstein, M.R., 2001. The identification, conservation, and management of estuarine and marine nurseries for fish and invertebrates. Bioscience 51, 633-641.

Bouchoucha, M., Brach-Papa, C., Gonzalez, J.-L., Lenfant, P., Darnaude, A., 2018. Growth, condition and metal concentration in juveniles of two Diplodus species in ports. Mar. Pollut. Bull. 126, 31-42.

Bouchoucha, M., Darnaude, A.M., Gudefin, A., Neveu, R., Verdoit-Jarraya, M., Boissery, P., Lenfant, P., 2016. Potential use of marinas as nursery grounds by rocky fishes: insights from four Diplodus species in the Mediterranean. Mar. Ecol.-Prog. Ser. 547, 193-209.

Breiman, L., 2001. Random Forests. Machine Learning 45, 5-32.

Campana, S.E., 1999. Chemistry and composition of fish otoliths: pathways, mechanisms and applications. Mar. Ecol.-Prog. Ser. 188, 263-297.

Campana, S.E., Chouinard, G.A., Hanson, J.M., Fréchet, A., Brattey, J., 2000. Otolith elemental fingerprints as biological tracers of fish stocks. Fisheries Research 46, 343-357.

Campana, S.E., Neilson, J.D., 1985. Microstructure of fish otoliths. Canadian Journal of Fisheries and Aquatic Sciences 42, 1014-1032.

Cheminee, A., Francour, P., Harmelin-Vivien, M., 2011. Assessment of Diplodus spp. (Sparidae) nursery grounds along the rocky shore of Marseilles (France, NW Mediterranean). Scientia Marina 75, 181-188.

Clarke, K.R., Warwick, R.M., 2001. Change in marine communities: an approach to statistical analysis and interpretation. PRIMER-E Limited Plymouth, UK.

Clynick, B.G., 2006. Assemblages of fish associated with coastal marinas in north-western Italy. Journal of the Marine Biological Association of the United Kingdom 86, 847-852.

Coffey, M., Dehairs, F., Collette, O., Luther, G., Church, T., Jickells, T., 1997. The behaviour of dissolved barium in estuaries. Estuarine, Coastal and Shelf Science 45, 113-121. 
Coll, J., Linde, M., García-Rubies, A., Riera, F., Grau, A.M., 2004. Spear fishing in the Balearic

380

381

382

383

384

385

386

387

388

389

390

391

392

393

394

395

396

397

398

399

400

401

402

403

404

405

406

407

408

409

410
Islands (west central Mediterranean): species affected and catch evolution during the period 19752001. Fisheries Research 70, 97-111.

Correia, A.T., Pipa, T., Goncalves, J.M.S., Erzini, K., Hamer, P.A., 2011. Insights into population structure of Diplodus vulgaris along the SW Portuguese coast from otolith elemental signatures. Fisheries Research 111, 82-91.

Dang, D.H., Schafer, J., Brach-Papa, C., Lenoble, V., Durrieu, G., Dutruch, L., Chiffoleau, J.F., Gonzalez, J.L., Blanc, G., Mullot, J.U., Mounier, S., Garnier, C., 2015. Evidencing the impact of coastal contaminated sediments on mussels through $\mathrm{Pb}$ stable isotopes composition. Environ. Sci. Technol. 49, 11438-11448.

Darbra, R.M., Ronza, A., Casal, J., Stojanovic, T.A., Wooldridge, C., 2004. The Self Diagnosis Method - A new methodology to assess environmental management in sea ports. Mar. Pollut. Bull. 48, 420-428.

Daverat, F., Lanceleur, L., Pécheyran, C., Eon, M., Dublon, J., Pierre, M., Schäfer, J., Baudrimont, M., Renault, S., 2012. Accumulation of Mn, Co, $\mathrm{Zn}, \mathrm{Rb}, \mathrm{Cd}, \mathrm{Sn}, \mathrm{Ba}, \mathrm{Sr}$, and $\mathrm{Pb}$ in the otoliths and tissues of eel (Anguilla anguilla) following long-term exposure in an estuarine environment. Science of The Total Environment 437, 323-330.

Davison, W., Zhang, H., 1994. In situ speciation measurements of trace components in natural waters using thin-film gels. Nature 367, 546-548.

Di Franco, A., De Benedetto, G., De Rinaldis, G., Raventos, N., Sahyoun, R., Guidetti, P., 2011. Large scale-variability in otolith microstructure and microchemistry: The case study of Diplodus sargus sargus (Pisces: Sparidae) in the Mediterranean Sea. Italian Journal of Zoology 78, 182-192.

Dierking, J., Morat, F., Letourneur, Y., Harmelin-Vivien, M., 2012. Fingerprints of lagoonal life: Migration of the marine flatfish Solea solea assessed by stable isotopes and otolith microchemistry. Estuarine Coastal and Shelf Science 104, 23-32.

Dufour, V., Cantou, M., Lecomte, F., 2009. Identification of sea bass (Dicentrarchus labrax) nursery areas in the north-western Mediterranean Sea. Journal of the Marine Biological Association of the United Kingdom 89, 1367-1374.

Elsdon, T.S., Gillanders, B.M., 2003. Reconstructing migratory patterns of fish based on environmental influences on otolith chemistry. Reviews in Fish Biology and Fisheries 13, 219-235.

Elsdon, T.S., Gillanders, B.M., 2004. Fish otolith chemistry influenced by exposure to multiple environmental variables. Journal of Experimental Marine Biology and Ecology 313, 269-284. 
Elsdon, T.S., Wells, B.K., Campana, S.E., Gillanders, B.M., Jones, C.M., Limburg, K.E., Secor, D.H., Thorrold, S.R., Walther, B.D., 2008. Otolith chemistry to describe movements and life-history parameters of fishes: Hypotheses, assumptions, limitations and inferences, in: Gibson, R.N., Atkinson, R.J.A., Gordon, J.D.M. (Eds.), Oceanography and Marine Biology: An Annual Review, Vol 46, pp. 297-+.

Fortunato, R.C., Dura, V.B., Volpedo, A., 2017. Otolith morphometry and microchemistry as habitat markers for juvenile Mugil cephalus Linnaeus 1758 in nursery grounds in the Valencian community, Spain. J. Appl. Ichthyol. 33, 163-167.

Friedrich, L.A., Halden, N.M., 2010. Determining exposure history of northern pike and walleye to tailings effluence using trace metal uptake in otoliths. Environ. Sci. Technol. 44, 1551-1558.

Friedrich, L.A., Halden, N.M., 2011. Laser ablation inductively coupled plasma mass spectrometric analyses of base metals in arctic char (Salvelinus alpinus) otoliths collected from a flooded base metal mine. Environ. Sci. Technol. 45, 4256-4261.

García-Rubies, A., Macpherson, E., 1995. Substrate use and temporal pattern of recruitment in juvenile fishes of the Mediterranean littoral. Mar. Biol. 124, 35-42.

Geffen, A.J., Pearce, N.J.G., Perkins, W.T., 1998. Metal concentrations in fish otoliths in relation to body composition after laboratory exposure to mercury and lead. Mar. Ecol.-Prog. Ser. 165, 235-245.

Gillanders, B.M., 2005. Using elemental chemistry of fish otoliths to determine connectivity between estuarine and coastal habitats. Estuarine Coastal and Shelf Science 64, 47-57.

Gillanders, B.M., Kingsford, M.J., 2000. Elemental fingerprints of otoliths of fish may distinguish estuarine 'nursery' habitats. Mar. Ecol.-Prog. Ser. 201, 273-286.

Guidetti, P., 2004. Fish assemblages associated with coastal defence structures in south-western Italy (Mediterranean Sea). Journal of the Marine Biological Association of the United Kingdom 84, 669670.

Halpern, B.S., Walbridge, S., Selkoe, K.A., Kappel, C.V., Micheli, F., D'Agrosa, C., Bruno, J.F., Casey, K.S., Ebert, C., Fox, H.E., Fujita, R., Heinemann, D., Lenihan, H.S., Madin, E.M.P., Perry, M.T., Selig, E.R., Spalding, M., Steneck, R., Watson, R., 2008. A global map of human impact on marine ecosystems. Science 319, 948-952.

Hamer, P.A., Jenkins, G.P., 2007. Comparison of spatial variation in otolith chemistry of two fish species and relationships with water chemistry and otolith growth. Journal of Fish Biology 71, 1035 1055. 
Hamer, P.A., Jenkins, G.P., Gillanders, B.M., 2005. Chemical tags in otoliths indicate the importance of local and distant settlement areas to populations of a temperate sparid, Pagrus auratus. Canadian Journal of Fisheries and Aquatic Sciences 62, 623-630.

Harmelin-Vivien, M.L., Harmelin, J.G., Leboulleux, V., 1995. Microhabitat requirements for settlement of juvenile sparid fishes on Mediterranean rocky shores. Hydrobiologia 300-301, 309-320.

Izzo, C., Doubleday, Z., Schultz, A., Woodcock, S., Gillanders, B., 2015. Contribution of water chemistry and fish condition to otolith chemistry: comparisons across salinity environments. Journal of Fish Biology 86, 1680-1698.

Izzo, C., Reis-Santos, P., Gillanders, B.M., 2018. Otolith chemistry does not just reflect environmental conditions: A meta-analytic evaluation. Fish and Fisheries 19, 441-454.

Jean, N., Dumont, E., Durrieu, G., Balliau, T., Jamet, J.L., Personnic, S., Garnier, C., 2012. Protein expression from zooplankton communities in a metal contaminated NW mediterranean coastal ecosystem. Marine Environmental Research 80, 12-26.

Jones, C.M., Palmer, M., Schaffler, J.J., 2017. Beyond Zar: the use and abuse of classification statistics for otolith chemistry. Journal of Fish Biology 90, 492-504.

Lloret, J., Zaragoza, N., Caballero, D., Font, T., Casadevall, M., Riera, V., 2008. Spearfishing pressure on fish communities in rocky coastal habitats in a Mediterranean marine protected area. Fisheries Research 94, 84-91.

Lotze, H.K., Lenihan, H.S., Bourque, B.J., Bradbury, R.H., Cooke, R.G., Kay, M.C., Kidwell, S.M., Kirby, M.X., Peterson, C.H., Jackson, J.B.C., 2006. Depletion, degradation, and recovery potential of estuaries and coastal seas. Science 312, 1806-1809.

Macpherson, E., Biagi, F., Francour, P., Garcia-Rubies, A., Harmelin, J., Harmelin-Vivien, M., Jouvenel, J.Y., Planes, S., Vigliola, L., Tunesi, L., 1997. Mortality of juvenile fishes of the genus Diplodus in protected and unprotected areas in the western Mediterranean Sea. Mar. Ecol.-Prog. Ser. 160, 135-147.

Mercader, M., Mercière, A., Saragoni, G., Cheminée, A., Crec'hriou, R., Pastor, J., Rider, M., Dubas, R., Lecaillon, G., Boissery, P., 2017. Small artificial habitats to enhance the nursery function for juvenile fish in a large commercial port of the Mediterranean. Ecol. Eng. 105, 78-86.

Mercier, L., Mouillot, D., Bruguier, O., Vigliola, L., Darnaude, A.M., 2012. Multi-element otolith fingerprints unravel sea-lagoon lifetime migrations of gilthead sea bream Sparus aurata. Mar. Ecol.Prog. Ser. 444, 175-194. 
Mercier, L., Panfili, J., Paillon, C., N'Diaye, A., Mouillot, D., Darnaude, A.M., 2011. Otolith reading and multi-model inference for improved estimation of age and growth in the gilthead seabream Sparus aurata (L.). Estuarine Coastal and Shelf Science 92, 534-545.

Morales-Nin, B., Moranta, J., García, C., Tugores, M.P., Grau, A.M., Riera, F., Cerdà, M., 2005. The recreational fishery off Majorca Island (western Mediterranean): some implications for coastal resource management. ICES Journal of Marine Science: Journal du Conseil 62, 727-739.

Odzak, N., Kistler, D., Xue, H., Sigg, L., 2002. In situ trace metal speciation in a eutrophic lake using the technique of diffusion gradients in thin films (DGT). Aquatic Sciences-Research Across Boundaries 64, 292-299.

Panfili, J., 2002. Manual of fish sclerochronology. Ifremer IRD coédition, Brest - France.

Pastor, J., Koeck, B., Astruch, P., Lenfant, P., 2013. Coastal man-made habitats: Potential nurseries for an exploited fish species, Diplodus sargus (Linnaeus, 1758). Fisheries Research 148, 74-80.

Pizzolon, M., Cenci, E., Mazzoldi, C., 2008. The onset of fish colonization in a coastal defence structure (Chioggia, Northern Adriatic Sea). Estuarine Coastal and Shelf Science 78, 166-178.

Pougnet, F., Schafer, J., Dutruch, L., Garnier, C., Tessier, E., Dang, D.H., Lanceleur, L., Mullot, J.U., Lenoble, V., Blanc, G., 2014. Sources and historical record of tin and butyl-tin species in a Mediterranean bay (Toulon Bay, France). Environmental Science and Pollution Research 21, 66406651.

R Core Team, 2014. R: A Language and Environment for Statistical Computing. R Foundation for Statistical Computing, Vienna, Austria.

Ranaldi, M.M., Gagnon, M.M., 2008. Trace Metal Incorporation in Otoliths of Black Bream (Acanthopagrus butcheri Munro), an Indicator of Exposure to Metal Contamination. Water, Air, and Soil Pollution 194, 31-43.

Ranaldi, M.M., Gagnon, M.M., 2009. Accumulation of cadmium in the otoliths and tissues of juvenile pink snapper (Pagrus auratus Forster) following dietary and waterborne exposure. Comparative Biochemistry and Physiology C-Toxicology \& Pharmacology 150, 421-427.

Regnier, T., Augley, J., Devalla, S., Robinson, C.D., Wright, P.J., Neat, F.C., 2017. Otolith chemistry reveals seamount fidelity in a deepwater fish. Deep-Sea Res. Part I-Oceanogr. Res. Pap. 121, 183-189.

Rodríguez-Rodríguez, D., Rees, S.E., Rodwell, L.D., Attrill, M.J., 2015. Assessing the socioeconomic effects of multiple-use MPAs in a European setting: A national stakeholders' perspective. Environ. Sci. Policy 48, 115-127. 
Ruitton, S., Francour, P., Boudouresque, C.F., 2000. Relationships between algae, benthic herbivorous invertebrates and fishes in rocky sublittoral communities of a temperate sea (Mediterranean). Estuarine Coastal and Shelf Science 50, 217-230.

Selleslagh, J., Echard, A., Pécheyran, C., Baudrimont, M., Lobry, J., Daverat, F., 2016. Can analysis of Platichthys flesus otoliths provide relevant data on historical metal pollution in estuaries? Experimental and in situ approaches. Science of The Total Environment 557, 20-30.

Søndergaard, J., Halden, N., Bach, L., Gustavson, K., Sonne, C., Mosbech, A., 2015. Otolith chemistry of common sculpins (Myoxocephalus scorpius) in a mining polluted Greenlandic fiord (Black Angel Lead-Zinc Mine, West Greenland). Water, Air, \& Soil Pollution 226, 336.

Sturrock, A.M., Hunter, E., Milton, J.A., Eimf, Johnson, R.C., Waring, C.P., Trueman, C.N., 2015. Quantifying physiological influences on otolith microchemistry. Methods in Ecology and Evolution 6, 806-816.

Sturrock, A.M., Trueman, C.N., Darnaude, A.M., Hunter, E., 2012. Can otolith elemental chemistry retrospectively track migrations in fully marine fishes? Journal of Fish Biology 81, 766-795.

Tanner, S.E., Vasconcelos, R.P., Reis-Santos, P., Cabral, H.N., Thorrold, S.R., 2011. Spatial and ontogenetic variability in the chemical composition of juvenile common sole (Solea solea) otoliths. Estuarine Coastal and Shelf Science 91, 150-157.

Tessier, E., Garnier, C., Mullot, J.U., Lenoble, V., Arnaud, M., Raynaud, M., Mounier, S., 2011. Study of the spatial and historical distribution of sediment inorganic contamination in the Toulon bay (France). Mar. Pollut. Bull. 62, 2075-2086.

Thorrold, S.R., Latkoczy, C., Swart, P.K., Jones, C.M., 2001. Natal Homing in a Marine Fish Metapopulation. Science 291, 297-299.

Tournois, J., Darnaude, A.M., Ferraton, F., Aliaume, C., Mercier, L., McKenzie, D.J., 2017. Lagoon nurseries make a major contribution to adult populations of a highly prized coastal fish. Limnology and Oceanography 62, 1219-1233.

Tournois, J., Ferraton, F., Velez, L., McKenzie, D.J., Aliaume, C., Mercier, L., Darnaude, A.M., 2013. Temporal stability of otolith elemental fingerprints discriminates among lagoon nursery habitats. Estuarine, Coastal and Shelf Science 131, 182-193.

Twiss, M.R., Moffett, J.W., 2002. Comparison of copper speciation in coastal marine waters measured using analytical voltammetry and diffusion gradient in thin-film techniques. Environ. Sci. Technol. 36, 1061-1068. 
Vasconcelos, R.P., Reis-Santos, P., Tanner, S., Fonseca, V., Latkoczy, C., Guenther, D., Costa, M.J., Cabral, H., 2007. Discriminating estuarine nurseries for five fish species through otolith elemental fingerprints. Mar. Ecol.-Prog. Ser. 350, 117-126.

Vasconcelos, R.P., Reis-Santos, P., Tanner, S., Maia, A., Latkoczy, C., Gunther, D., Costa, M.J., Cabral, H., 2008. Evidence of estuarine nursery origin of five coastal fish species along the Portuguese coast through otolith elemental fingerprints. Estuarine Coastal and Shelf Science 79, 317-327.

Ventura, D., Jona Lasinio, G., Ardizzone, G., 2014. Temporal partitioning of microhabitat use among four juvenile fish species of the genus Diplodus (Pisces: Perciformes, Sparidae). Marine Ecology, 120.

Vigliola, L., 1997. Validation of daily increment formation in otoliths for three Diplodus species in the Mediterranean sea. Journal of Fish Biology 51, 349-360.

Vigliola, L., Harmelin-Vivien, M., 2001. Post-settlement ontogeny in three Mediterranean reef fish species of the genus Diplodus. Bulletin of Marine Science 68, 271-286.

Vigliola, L., Harmelin-Vivien, M.L., Biagi, F., Galzin, R., Garcia-Rubies, A., Harmelin, J.G., Jouvenel, J.Y., Le Direach-Boursier, L., Macpherson, E., Tunesi, L., 1998. Spatial and temporal patterns of settlement among sparid fishes of the genus Diplodus in the northwestern Mediterranean. Mar. Ecol.-Prog. Ser. 168, 45-56.

Wafo, E., Abou, L., Nicolay, A., Boissery, P., Perez, T., Abondo, R.N., Garnier, C., Chacha, M., Portugal, H., 2016. A chronicle of the changes undergone by a maritime territory, the Bay of Toulon (Var Coast, France), and their consequences on PCB contamination. SpringerPlus 5.

Zhang, H., Davison, W., 2001. In situ speciation measurements. Using diffusive gradients in thin films (DGT) to determine inorganically and organically complexed metals. Pure and Applied Chemistry 73, 9-15.

Zhang, H., Davison, W., Miller, S., Tych, W., 1995. In situ high resolution measurements of fluxes of $\mathrm{Ni}, \mathrm{Cu}, \mathrm{Fe}$, and $\mathrm{Mn}$ and concentrations of $\mathrm{Zn}$ and $\mathrm{Cd}$ in porewaters by DGT. Geochimica Et Cosmochimica Acta 59, 4181-4192. 
571

572

573

574

575

576

577 Figure 1: Map of the Bay of Toulon (Northwestern Mediterranean) showing the location of the five

578 sites sampled for this study. The sites located inside ports are represented by black circles while

579 those located outside them are represented by white circles.

580 


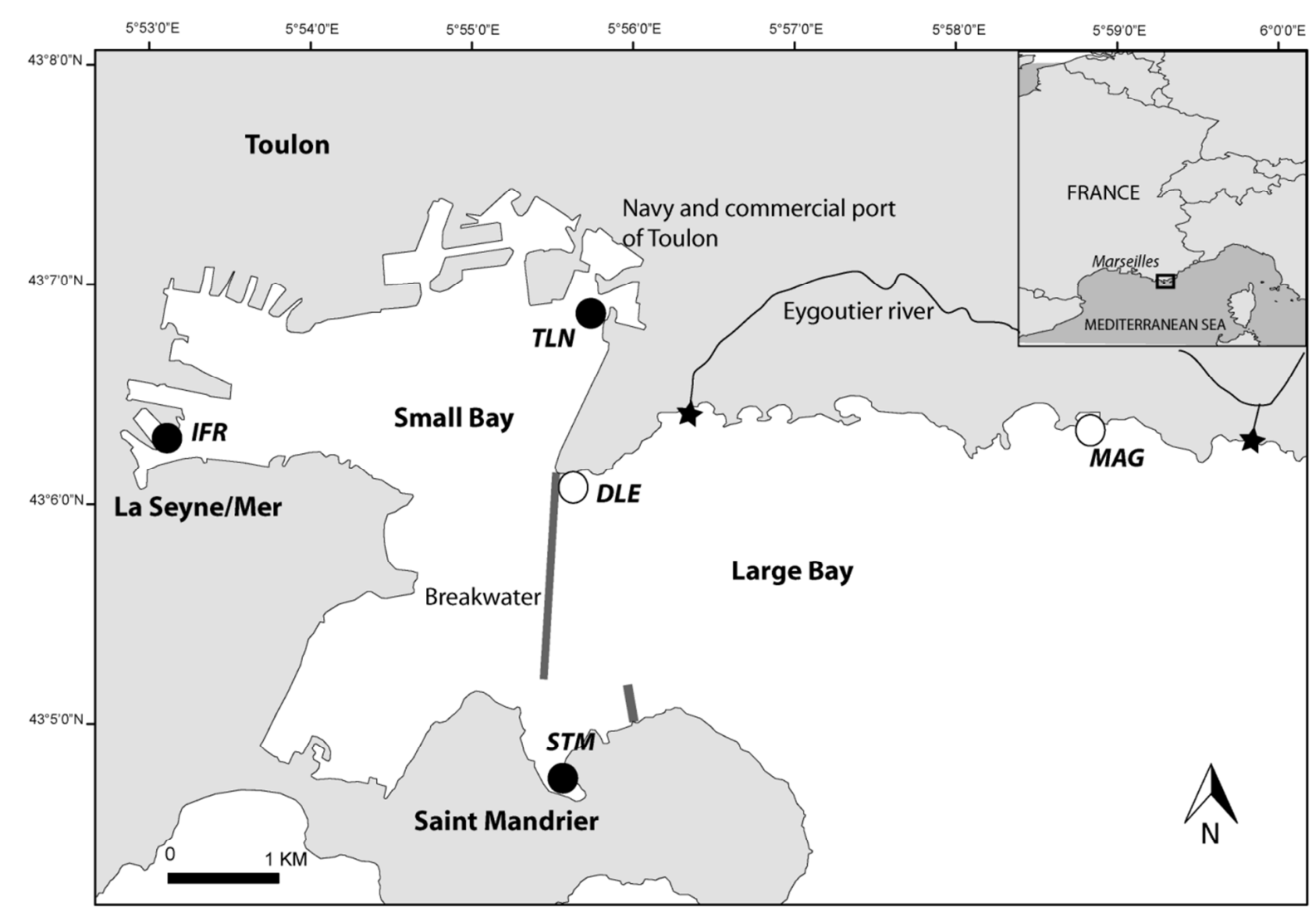

581

582

Figure 2: Cross section though a sagittal otolith of juvenile D. sargus. The $150 \mathrm{x} 150 \mu \mathrm{m}$ ablation area, represented by the grey square (a), is positioned $200 \mu \mathrm{m}$ after the settlement mark. 


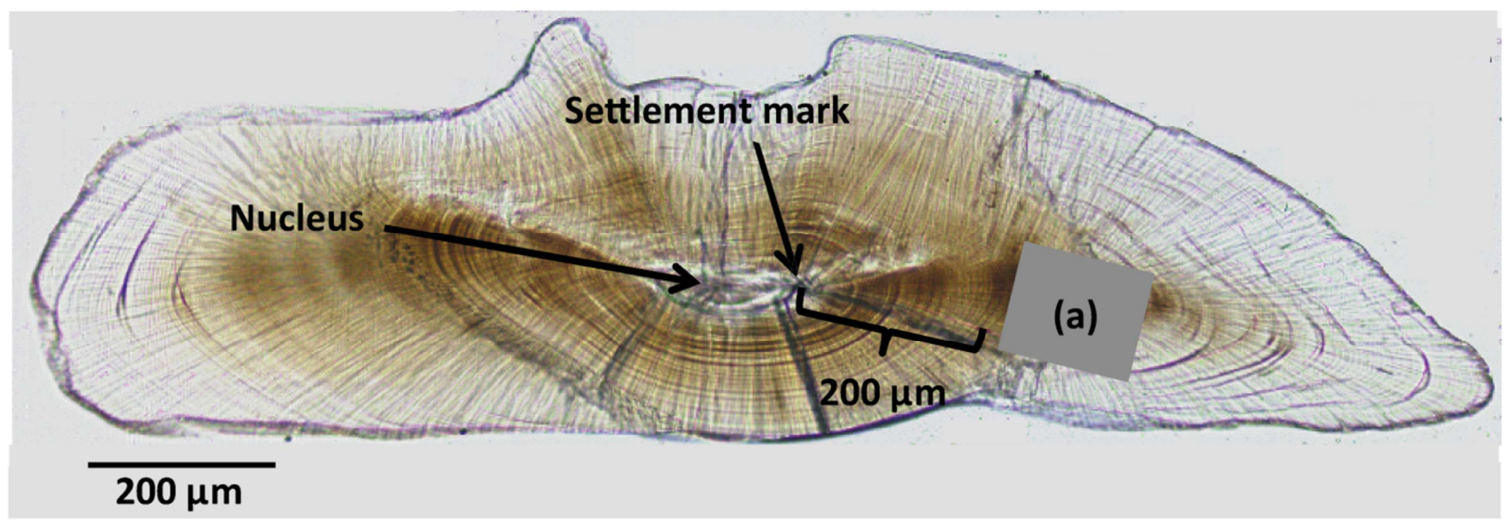

594

595

596

597

598 
Figure 3: Mean otolith element:Ca ratios ( $\pm \mathrm{SE})$ measured for $\mathrm{Ba}, \mathrm{Mn}, \mathrm{Sr}, \mathrm{Cu}, \mathrm{Pb}, \mathrm{V}, \mathrm{Mg}, \mathrm{Sn}$ and $\mathrm{Zn}$ in the juveniles of D. sargus and D. vulgaris from the two habitat types (In, inside ports, Out, outside ports) and the five sampling sites (M, MAG ; D, DLE ; S, STM ; T, TLN ; I, IFR). For each species, letters indicate significant differences $(\mathrm{p}<0.05)$ between habitat types or sampling sites (see M\&M for details). 

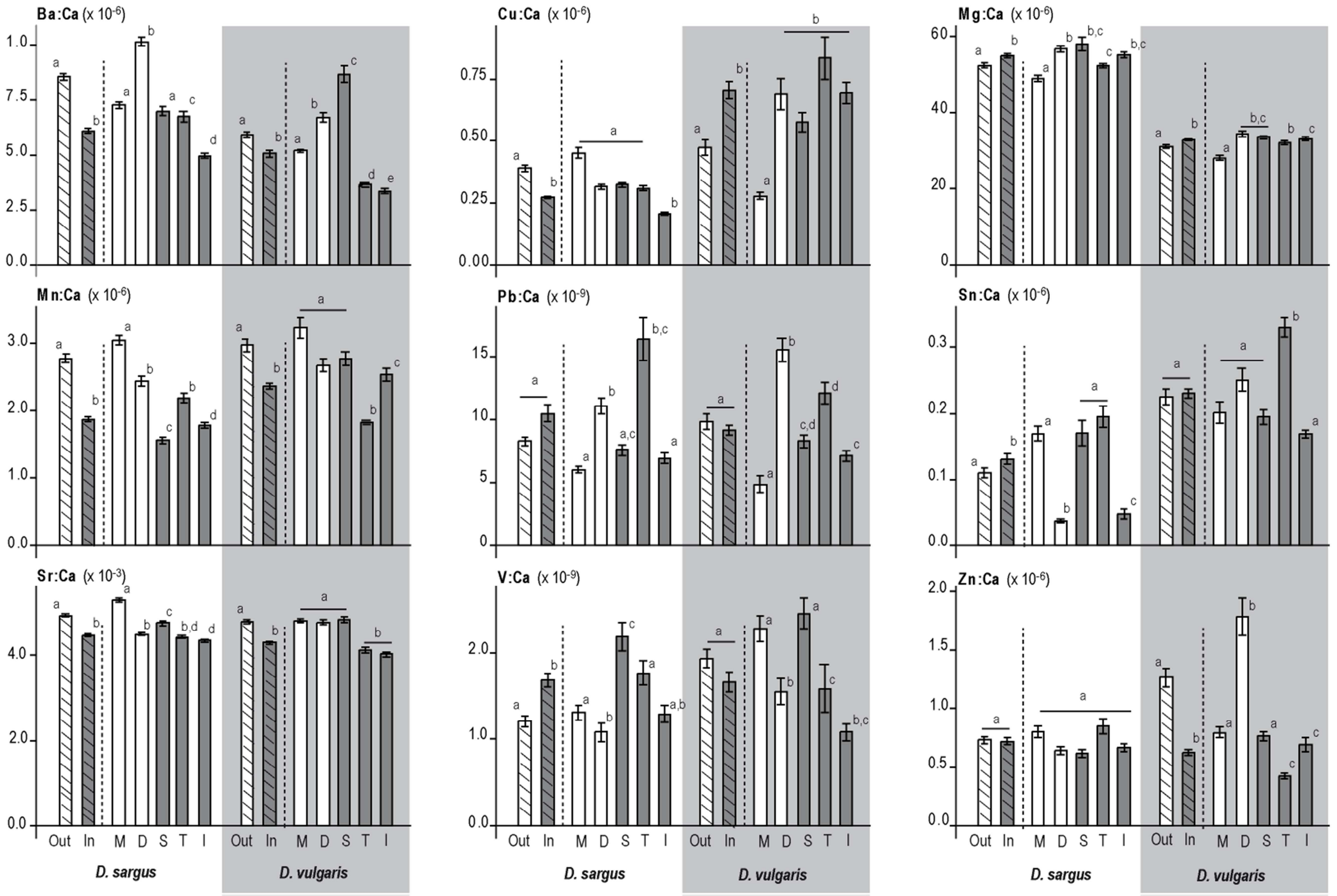
Figure 4: Effect of elemental combination size and composition on the discrimination accuracy obtained using the RF method: (a) between the two habitat types for D. sargus, (b) among the five sampling sites for D. sargus, (c) between the two habitat types for D. vulgaris and (d) among the five sampling sites for $D$. vulgaris (d). The grey area on the graph represents the range between the minimal and maximal accuracies reached for each combination size while the corresponding average accuracy $( \pm \mathrm{SD})$ is represented by the black square. The table gives the list of elements that achieved maximal discrimination with the corresponding mean decreases in the Gini index (see text for details). 


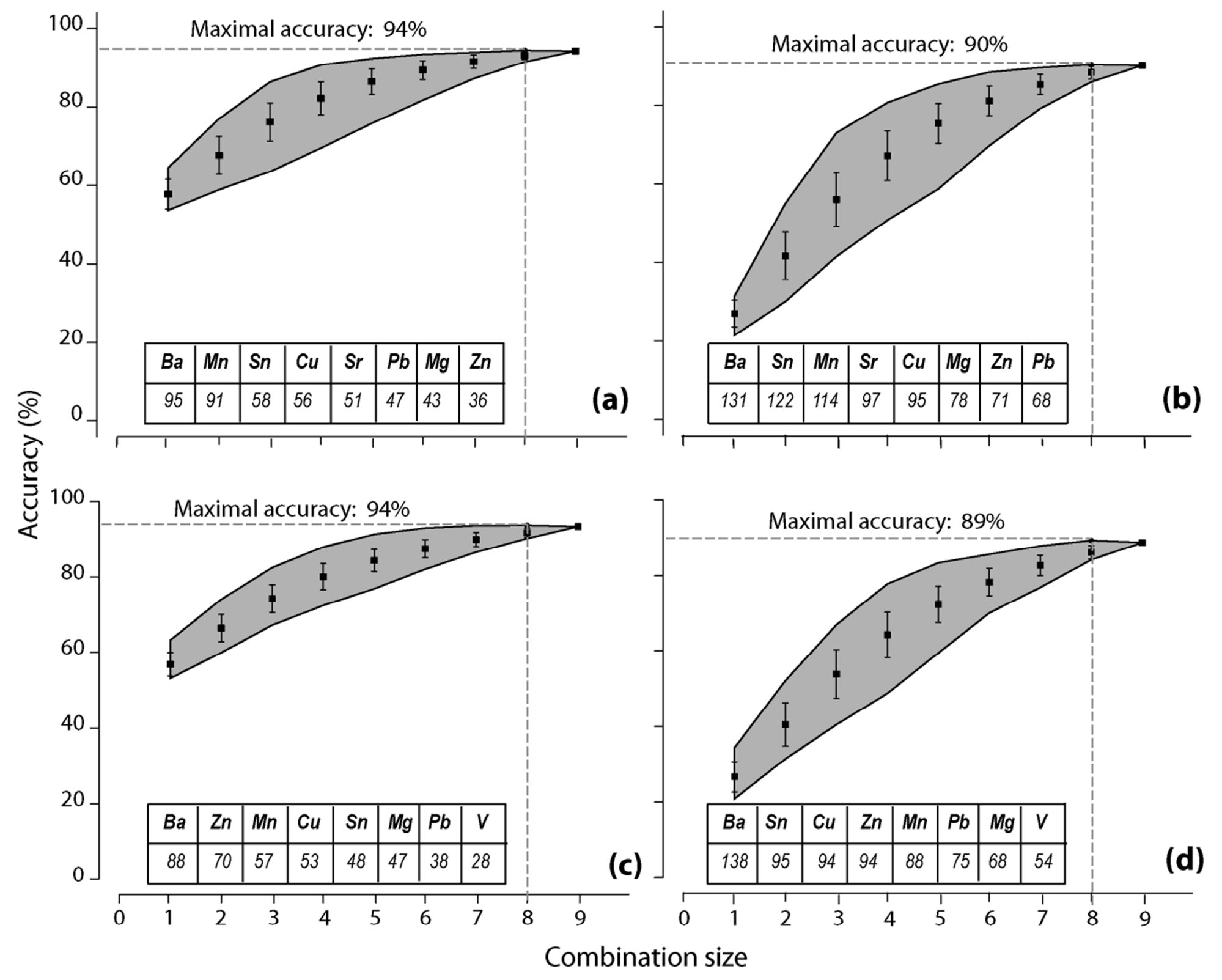


Table 1: Concentrations in trace elements in the water column for the five sampling sites measured with DGT. Letters indicate significant differences ( $<<0.05)$ between sites if any

\begin{tabular}{|c|c|c|c|c|c|c|c|c|c|c|c|c|}
\hline \multirow[b]{2}{*}{ site } & \multicolumn{2}{|c|}{ Temp. $\left({ }^{\circ} \mathrm{C}\right)$} & \multicolumn{2}{|c|}{ Salinity (psu) } & \multicolumn{2}{|c|}{$\mathrm{Cu}\left(\mathrm{ng} . \mathrm{I}^{-1}\right)$} & \multicolumn{2}{|c|}{$\operatorname{Mn}\left(\mu \mathrm{g} . I^{-1}\right)$} & \multicolumn{2}{|c|}{$\mathrm{Pb}\left(\mathrm{ng} . \mathrm{I}^{-1}\right)$} & \multicolumn{2}{|c|}{$\mathrm{Zn}\left(\mu \mathrm{g} . \mathrm{I}^{-1}\right)$} \\
\hline & Mean $\pm \mathrm{sd}$ & Min-Max & Mean $\pm s d$ & Min-Max & Mean \pm sd & Min-Max & Mean \pm sd & Min-Max & Mean \pm sd & Min-Max & Mean \pm sd & Min-Max \\
\hline TLN & $17.5 \pm 4.3$ & $12.8-24.8$ & $37.1 \pm 1.0$ & $35.1-38.8$ & $1268 \pm 572^{(a . b)}$ & $842-2203$ & $0.83 \pm 0.49^{(a)}$ & $0.43-1.62$ & $328 \pm 107^{(\mathrm{a})}$ & $206-540$ & $3.05 \pm 1.67^{(\mathrm{a})}$ & $1.52-6.03$ \\
\hline IFR & $17.6 \pm 4.8$ & $12.0-25.7$ & $37.2 \pm 1.9$ & $32.2-38.7$ & $879 \pm 261$ & $589-1205$ & $1.28 \pm 0.59^{(a)}$ & $0.76-2.22$ & $203 \pm 85^{\text {(a.b) }}$ & $132-337$ & $3.44 \pm 1.42^{\text {(a) }}$ & $1.72-5.36$ \\
\hline STM & $17.7 \pm 4.9$ & $12.0-25.4$ & $37.8 \pm 1.3$ & $34.4-39.5$ & $2972 \pm 997^{\text {(a) }}$ & $1593-4375$ & $0.67 \pm 0.20^{(a)}$ & $0.48-0.90$ & $222 \pm 47^{(\mathrm{a})}$ & $153-261$ & $3.27 \pm 0.78^{(a)}$ & $2.32-4.30$ \\
\hline DLE & $17.1 \pm 3.9$ & $12.6-23.6$ & $38.0 \pm 0.8$ & $35.8-39.0$ & $257 \pm 166^{(\mathrm{c})}$ & $142-498$ & $1.52 \pm 1.18^{(a)}$ & $0.57-3.12$ & $86 \pm 44^{(b . c)}$ & $52-145$ & $1.47 \pm 1.26^{(\mathrm{a})}$ & $0.50-3.17$ \\
\hline MAG & $17.4 \pm 4.1$ & $13.2-25.5$ & $38.0 \pm 0.5$ & $37.2-39.1$ & $87 \pm 38^{(c)}$ & $39-145$ & $0.50 \pm 0.16^{(\mathrm{a})}$ & $0.40-0.78$ & $47 \pm 10^{(c)}$ & $36-61$ & $1.31 \pm 0.96^{(a)}$ & $0.26-2.79$ \\
\hline
\end{tabular}


Table 2: Classification accuracy and True Skill Statistics (TSS) per habitat type or per sampling site reached for D. sargus and D. vulgaris with RF using the optimal elemental combination. 


\begin{tabular}{|c|c|c|c|c|c|c|c|}
\hline & $\begin{array}{c}\text { Inside } \\
\text { ports }\end{array}$ & TLN & IFR & STM & $\begin{array}{c}\text { Outside } \\
\text { ports }\end{array}$ & DLE & MAG \\
\hline \multicolumn{8}{|l|}{ a) D. sargus } \\
\hline Inside ports & 95.3 & & & & 6.7 & & \\
\hline TLN & & 88.1 & 2.6 & 4.4 & & 0.6 & 0.8 \\
\hline IFR & & 6.7 & 88.7 & 6.3 & & 1.1 & 0.9 \\
\hline STM & & 1.1 & 2.4 & 76.1 & & 0.8 & 0.7 \\
\hline Outside Ports & 4.7 & & & & 93.3 & & \\
\hline DLE & & 1.4 & 3.2 & 6.1 & & 97.2 & 0.3 \\
\hline MAG & & 2.7 & 3 & 7.2 & & 0.3 & 97.3 \\
\hline TSS & 0.89 & 0.86 & 0.85 & 0.75 & 0.89 & 0.95 & 0.94 \\
\hline \multicolumn{8}{|l|}{ b) D. vulgaris } \\
\hline Inside ports & 95.3 & & & & 8.6 & & \\
\hline TLN & & 91.7 & 5.7 & 0.5 & & 1.0 & 1.3 \\
\hline IFR & & 4.3 & 88.8 & 3.0 & & 1.5 & 1.4 \\
\hline STM & & 0.4 & 1.7 & 85.9 & & 4.6 & 1.4 \\
\hline Outside ports & 4.7 & & & & 91.4 & & \\
\hline DLE & & 1.7 & 2.1 & 4.3 & & 86.3 & 2.8 \\
\hline MAG & & 1.8 & 1.8 & 6.4 & & 6.5 & 93.1 \\
\hline TSS & 0.87 & 0.90 & 0.86 & 0.84 & 0.87 & 0.84 & 0.89 \\
\hline
\end{tabular}

